\title{
Symptomatic lower limb large vessel vasculitis presenting as fever of unknown origin diagnosed on FDG-PET/CT
}

\author{
Angela Mujukian, ${ }^{1}$ Michael Kay, ${ }^{2}$ Jonathan Lewis Marks ${ }^{3}$
}

\begin{abstract}
${ }^{1}$ Medical Student, St. George's University School of Medicine, Poole Hospital NHS Foundation Trust, Poole, UK

${ }^{2}$ Consultant, Department of Radiology \& Nuclear Medicine, Poole Hospital NHS Foundation Trust, Poole, UK

${ }^{3}$ Consultant, Department of Rheumatology, Royal Bournemouth and Christchurch Hospitals NHS Foundation Trust, Christchurch, UK
\end{abstract}

Correspondence to Angela Mujukian, angela.mujukian@poole.nhs.uk

Accepted 11 January 2018

\section{DESCRIPTION}

A 75-year-old man with a 6-month history of unexplained weight loss and malaise presented with fever and rigours, severe thigh pain and proximal myopathy. C-reactive protein and erythrocyte sedimentation rate were raised $(373 \mathrm{mg} /$ $\mathrm{dL}$ and $58 \mathrm{~mm} /$ hour, respectively) with a normal creatine kinase. A diagnosis of giant cell arteritis (GCA) was considered despite the absence of typical cranial symptoms and a temporal artery biopsy (TAB) was performed. TAB showed an unusual perivascular inflammatory pattern felt to be in keeping with the clinical picture of vasculitis but did not demonstrate the classical transmural inflammation typically seen in GCA.

In view of the lower limb symptoms, fluorodeoxyglucose-positron emission tomography/CT imaging was performed which showed increased tracer uptake, compatible with vasculitis, predominantly affecting the peripheral lower limb vessels (figure 1) with relative sparing of larger vessels in the lower extremities. Axillary and subclavian artery involvement, more typical

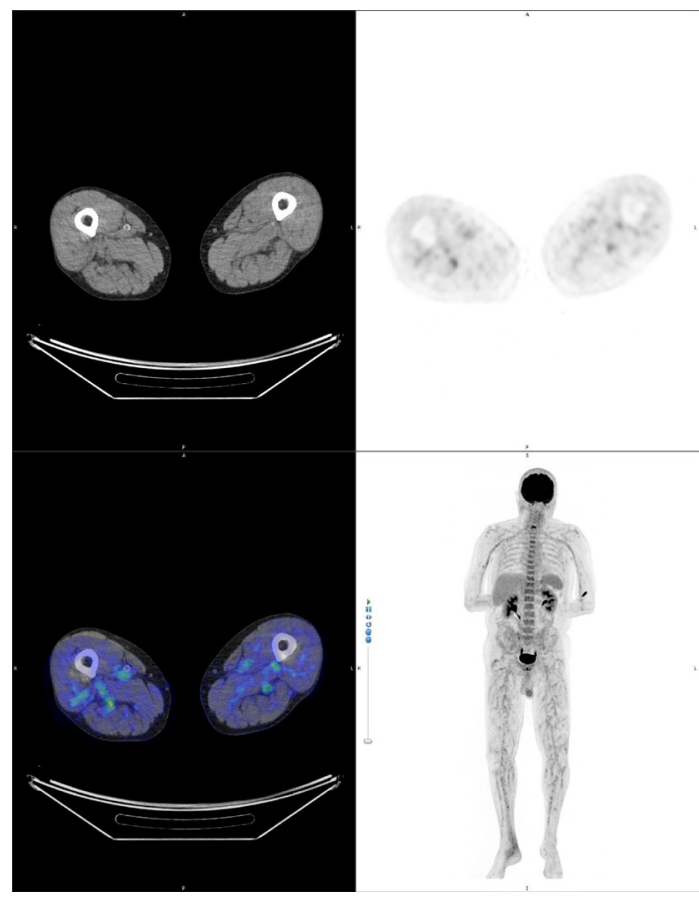

Figure 1 Axial image through the thighs shows increased activity within vessels and a relative paucity of muscular uptake on fluorodeoxyglucose-positron emission tomography (FDG-PET)/CT.

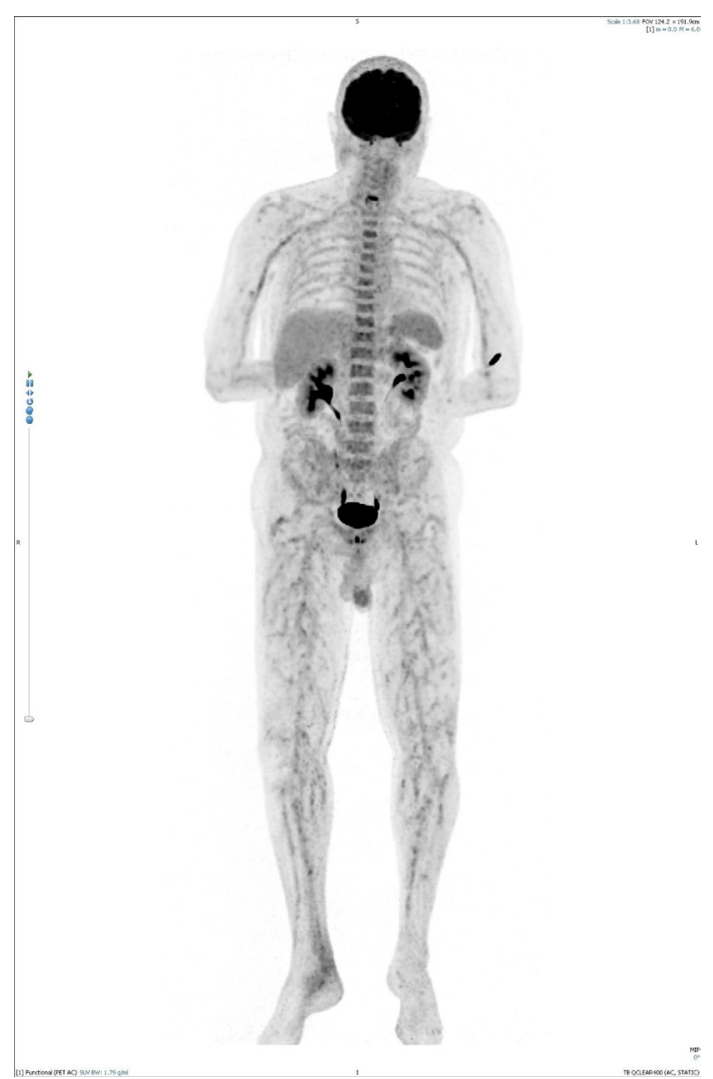

Figure 2 Whole-body maximum intensity projection (MIP) demonstrates increased tracer uptake in the larger vessels of the lower limbs with sparing of the aorta, iliac and femoral arteries. Increased uptake is also displayed in the axillary and subclavian arteries.

for GCA, was clearly demonstrated on imaging (figure 2).

Commencement of high-dose oral prednisolone (60 mg daily) resulted in the complete resolution of symptoms within 24 hours and symptoms have remained quiescent following a gradual steroid taper.

GCA is the most common form of large vessel vasculitis affecting around 1 in 5000 people over the age of $50 .^{1}$ Predominant lower extremity involvement is an unusual pattern in GCA, which more typically involves the aorta, aortic arch and branches thereof with the temporal vessels most commonly symptomatic. Patients with lower extremity involvement may not exhibit cranial symptoms such as headache despite the presence of positive TAB. ${ }^{2}$ While symptomatic lower limb 
vasculitis is rare, it can be associated with significant morbidity due to the potential for critical limb ischaemia. ${ }^{3}$

\section{Learning points}

- Giant cell arteritis is a recognised cause of fever of unknown origin and can present with predominant lower limb involvement in the absence of typical cranial symptoms.

- Fluorodeoxyglucose-positron emission tomography/CT scanning can be helpful in identifying vascular inflammation that is not clinically evident, enabling prompt treatment to prevent ischaemic complications.

Contributors AM contributed to conception and design, acquisition of data analysis, literature reviews with citations, and drafting and revision of manuscript. MK was involved in patient care, extraction of images, figure captions, and drafting and revision of manuscript. JLM was involved in patient care, patient consent, and drafting and revision of manuscript. All authors (AM, MK, JLM) are in full agreement and take full responsibility for the article and ensure that all questions regarding the accuracy and integrity of the article were investigated and resolved.

Funding This research received no specific grant from any funding agency in the public, commercial or not-for-profit sectors.

Competing interests None declared.

Patient consent Obtained.

Provenance and peer review Not commissioned; externally peer reviewed.

(c) BMJ Publishing Group Ltd (unless otherwise stated in the text of the article) 2018. All rights reserved. No commercial use is permitted unless otherwise expressly granted.

\section{REFERENCES}

1 Smeeth L, Cook C, Hall AJ, et al. Incidence of diagnosed polymyalgia rheumatica and temporal arteritis in the United Kingdom, 1990-2001. Ann Rheum Dis 2006;65:1093-8.

2 Assie C, Janvresse A, Plissonnier D, et al. Long-term follow-up of upper and lower extremity vasculitis related to giant cell arteritis: a series of 36 patients. Medicine 2011:90:40-51.

3 Kermani TA, Matteson EL, Hunder GG, et al. Symptomatic lower extremity vasculitis in giant cell arteritis: a case series. J Rheumatol 2009;36:2277-83.

Copyright 2017 BMJ Publishing Group. All rights reserved. For permission to reuse any of this content visit http://group.bmj.com/group/rights-licensing/permissions.

BMJ Case Report Fellows may re-use this article for personal use and teaching without any further permission.

Become a Fellow of BMJ Case Reports today and you can:

- Submit as many cases as you like

- Enjoy fast sympathetic peer review and rapid publication of accepted articles

- Access all the published articles

Re-use any of the published material for personal use and teaching without further permission

For information on Institutional Fellowships contact consortiasales@bmjgroup.com

Visit casereports.bmj.com for more articles like this and to become a Fellow 